
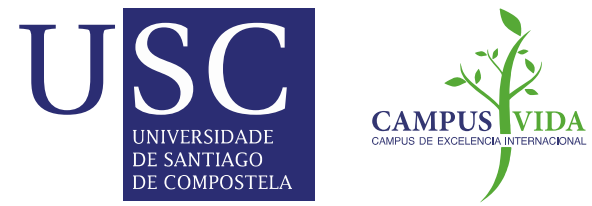

\title{
An optimised control system to steer the transition from anaerobic mono- to co-digestion in full-scale plants
}

Anton Taboada-Santos, Marta Carballa, Nicolás Morales, Jose R. Vázquez-Padín, Ramiro Gutierrez and Juan M. Lema

\section{Accepted Mansucript}

\section{How to cite:}

Taboada-Santos, A., Carballa, M., Morales, N., Vázquez-Padín, J., Gutierrez, R., \& Lema, J. (2019). An optimised control system to steer the transition from anaerobic mono- to co-digestion in fullscale plants. Environ. Sci.: Water Res. Technol., 5, 1004-1011. doi: 10.1039/c9ew00033j

\section{Copyright information:}

(C) The Royal Society of Chemistry 2019 


\section{Environmental Science: Water Research and Technology}

\section{ARTICLE}

\section{An optimised control system to steer the transition from anaerobic mono- to co-digestion at full-scale plants}

Received 00th January 20xx, Accepted 00th January 20xx

DOI: $10.1039 / x 0 x \times 00000 x$

www.rsc.org/

\author{
Anton Taboada-Santos ${ }^{a,}{ }^{,}$, Marta Carballa ${ }^{a}$, Nicolás Morales ${ }^{b}$, Jose R. Vázquez- \\ Padín $^{b}$, Ramiro Gutierrez ${ }^{b}$, and Juan M. Lema ${ }^{a}$
}

\begin{abstract}
Traditional wastewater treatment plants (WWTPs) are electrical consumers, with a usual high demand in the range of 0.3 to $0.6 \mathrm{kWh} / \mathrm{m}^{3}$ of wastewater treated. Their digesters are commonly oversized, and consequently operated at low organic loading rates (OLRs). This opens a great opportunity for anaerobic co-digestion (AcoD) as an interesting technology to increase methane productivity and the electrical self-production in WWTPs. However, there is a quite limited implementation of $A c O D$ at full-scale plants, since the transition from mono- to co-digestion and the further AcoD optimisation is a crucial and delicate step that could lead to the inhibition of the process if not thoroughly controlled. In this study, a methodology based on an optimum control strategy is explained in detail and it was applied to safely and optimally steer the transition from mono- to co-digestion and to maximize methane production during AcoD. A lab-scale anaerobic digester of $14 \mathrm{~L}$ mimicking the full-scale one $\left(3,500 \mathrm{~m}^{3}\right)$ was operated 30 days in advance to anticipate and if needed correct any operational destabilization that might occurr. As a result, the treatment of sewage sludge with two co-substrates (coming from a pig slaughterhouse and from a frying industry), which accounted for just $11 \%$ of the feeding flowrate, at a hydraulic retention time of 20 days allowed to raise the OLR and the methane production by 2-fold and 3-fold, respectively, increasing the self-produced electricity from $25 \%$ to $75 \%$ of the total demand of the WWTP. The diagnosis indicators proved to be accurate to take decisions concerning wastes blending and the strategy of increasing OLR. Besides, the proposed control system provides the steps to ensure a safe transition from anaerobic mono- to co-digestion and further optimisation at full-scale plants.
\end{abstract}

\section{Introduction}

Recent studies suggest that novel wastewater treatment plants (WWTPs), can reach the energy autarky or even being net electrical producers. ${ }^{1,2}$. However, traditional WWTPs, based on the nitrification-denitrification process, are great electrical consumers with an usual demand in the range of 0.3 to 0.6 $\mathrm{kWh} / \mathrm{m}^{3}$ wastewater treated. ${ }^{3,4}$ Actually, data from European countries show that electricity demand for wastewater treatment accounts for about 1-3\% of total consumption of the country. 5,6

In WWTPs sludge digesters are commonly oversized in order to face punctual situations of high sewage sludge generation and to avoid process disturbances; ${ }^{7,8}$ consequently, they are often run at very conservative organic loading rates (OLRs). Therefore, there is room to substantially increase their methane production and subsequent self-produced energy through anaerobic co-digestion (AcoD) by including other wastes (co-

a. Department of Chemical Engineering, School of Engineering, Universidade de Santiago de Compostela, E-15782, Santiago de Compostela, Spain.

b. Aqualia, Guillarei WWTP, Camino de la Veiga s/n, E-36720 Tui, Spain

Electronic Supplementary Information (ESI) available: [details of any supplementary information available should be included here]. See DOI: 10.1039/x0xx00000x substrates), decreasing the WWTP energy demand and even transforming them in net electrical producers.

There are many kinds of organic wastes suitable for AcoD and since Directive 99/31/EC enforces to phase out the amount of biodegradable waste entering landfills, their valorisation through AcoD becomes a very attractive option. Initially, cosubstrates were chosen with the aim to balance several parameters in the feed-mixture, such as inhibitors/toxic compounds, carbon to nitrogen ratio, $\mathrm{pH}$ or moisture. ${ }^{9}$ However, with the objective of increasing biogas production, nowadays co-substrates providing high and easily biodegradable organic matter are preferable. ${ }^{10}$ Therefore, AcoD becomes beneficial not only for WWTPs (reducing their electrical demand) but also for the industries generating biodegradable organic wastes by reducing their volume and management costs.

There was a rapid increase in the number of AcoD studies at labscale over the last years. ${ }^{11}$ However, the very limited number of pilot- and full-scale studies available in the literature is a major hurdle to the transfer of technological know-how to full-scale AcoD implementation, ${ }^{12,13}$. Moreover, the few works in the literature dealing with $A c o D$ at full-scale facilities normally do 
not indicate how they steer the transition from mono- to codigestion and how they guarantee a safe operation, despite the great economic benefits of self-produced biogas and electricity they report.12,14,15 Therefore, WWTPs operators prefer to prevent from damaging the microbial consortium, which is not adapted to the different substrates, what might interrupt or even stop the process. ${ }^{16,17}$

To face this limitation, Garcia-Gen et al. (2015) ${ }^{18}$ developed a robust control system based on linear programming ${ }^{19}$ with control principles. Despite this system was developed for an hybrid Upflow Anaerobic Sludge Blanket-Anaerobic Filter reactor to treat liquid wastes, it can be useful for other reactor configurations and solid co-substrates.

The objective of this work is to adapt and apply a control system methodology to safely steer the transition from anaerobic mono- to co-digestion and to maximize its methane production in a full-scale sludge digester.

\section{Materials and methods}

\section{Wastewater treatment plant configuration}

This work was conducted in WWTP of Guillarei, located in the northwest of Spain. It was designed for 132,000 population equivalents and an average wastewater flowrate of $1,700 \mathrm{~m}^{3} / \mathrm{h}$. The wastewater treatment consists of three main sections: pretreatment, primary treatment and secondary treatment. After wastewater reception, pretreatment comprises bar racks for coarse screening and aerated chambers for grit and fat removal. Primary treatment is carried out in circular sedimentation tanks, and finally, secondary treatment is carried out in biological reactors using the conventional activated sludge process (mixed reactors followed by a sedimentation tank). The supernatant of the secondary settlers constitutes the final effluent of the WWTP. The solids obtained in the primary sedimentation and the excess of secondary sludge are concentrated in gravity and drum thickeners, respectively, mixed and fed to the anaerobic digester.

\section{Full-scale and lab-scale anaerobic digesters}

The full-scale anaerobic digester has a working volume of 3,500 $\mathrm{m}^{3}$ and is operated under mesophilic conditions with an OLR of 1.2-1.5 $\mathrm{kg} \mathrm{COD} /\left(\mathrm{m}^{3} \cdot \mathrm{d}\right)$. The sewage sludge flowrate is $4,000-4,500$ $\mathrm{m}^{3} /$ month, resulting in an average hydraulic retention time (HRT) of 25 days.

One continuous stirred (IKA RW20, $150 \mathrm{rpm}$ ) tank lab-scale reactor (CSTR), made of stainless steel with a working volume of $14 \mathrm{~L}$ was operated semi-continuously (once a day draw-off and feeding) in mesophilic range $(37 \pm 1$ 으. . This reactor mimicked the full-scale one, but it allowed to perform a more detailed monitoring during the transition to AcoD. The lab-scale anaerobic digester was operated 30 days in advance to the full-scale one in order to prevent any destabilization or failure in the full-scale digester. After inoculation with biomass taken from the full-scale digester (in-reactor concentration of $11.5 \mathrm{~g} \mathrm{VSS} / \mathrm{kg}$ ), during period I (days 0-12), the reactor was only fed with sewage sludge and operated with a HRT of 30 days (OLR of $1.3 \mathrm{~g} \mathrm{COD/(L \cdot d)).} \mathrm{From} \mathrm{day} 13$ on, the control strategy was applied to maximize methane production.
Feeding mixture characteristics (COD, total solids (TS), volatile solids (VS), total Kjeldahl nitrogen (TKN), and total ammonium nitrogen (TAN)) were measured once per week. Reactor temperature, stirring speed and biogas flow were monitored online. Biogas composition was daily measured, whereas $\mathrm{pH}$, alkalinity and other reactor parameters (COD, TS, VS, TKN, TAN and volatile fatty acids concentration (VFA)) were determined off-line three times per week, respectively.

\section{Sewage sludge and co-substrates}

Sewage sludge was a mix of primary $(60-70 \% \mathrm{w} / \mathrm{w})$ and biological $(30-40 \% \mathrm{w} / \mathrm{w})$ sludge from the sludge thickeners, respectively. The two co-substrates ( $A$ and $B$ ) were taken from a pig slaughterhouse and from a frying industry, respectively. Several batches of the three residues were used throughout the experimental period due to the impossibility of storage of the entire amount needed. Every batch was characterised in terms of $\mathrm{pH}, \mathrm{COD}, \mathrm{TS}, \mathrm{VS}, \mathrm{TKN}, \mathrm{TAN}$, total alkalinity (TA), partial alkalinity (PA) and VFA.

\section{Biomethane potential tests}

The biochemical methane potential (BMP) of each waste was determined in $500 \mathrm{~mL}$ bottles ( $375 \mathrm{~mL}$ of working volume) in triplicate following the protocol described elsewhere ${ }^{20}$ The bottles were filled with inoculum taken from the full-scale digester and diluted till $4 \mathrm{~g}$ VSS/L, macro- and micro-nutrient solution, resazurin, L-cysteine and $\mathrm{NaHCO}_{3}$ and $\mathrm{pH}$ was adjusted to 7-7.5 with $\mathrm{NaOH}$ or $\mathrm{HCl}$. After substrate addition ( $4 \mathrm{~g} \mathrm{COD} / \mathrm{L}$ ), volume was adjusted to $375 \mathrm{~mL}$ with distilled water and liquid phase was bubbled with $\mathrm{N}_{2}$ and bottles were sealed with rubber stoppers and capped with plastic seals. After flushing the head space with $\mathrm{N}_{2}$, bottles were incubated in a shaker $(150 \mathrm{rpm})$ at $37^{\circ} \mathrm{C}$. Biogas production and composition were measured daily during the first five days, each two days between the sixth and the eleventh day and each three or four days from the twelfth day till the end of the test.

\section{Control strategy for maximum AcoD performance}

The modification of the control strategy developed by Garcia-Gen et al. (2015) ${ }^{18}$ is presented in Figure 1. It comprises four blocks: (1) Substrates Blender, (2) Filter, (3) Diagnosis and (4) Controller. A detailed description of each module is provided below.

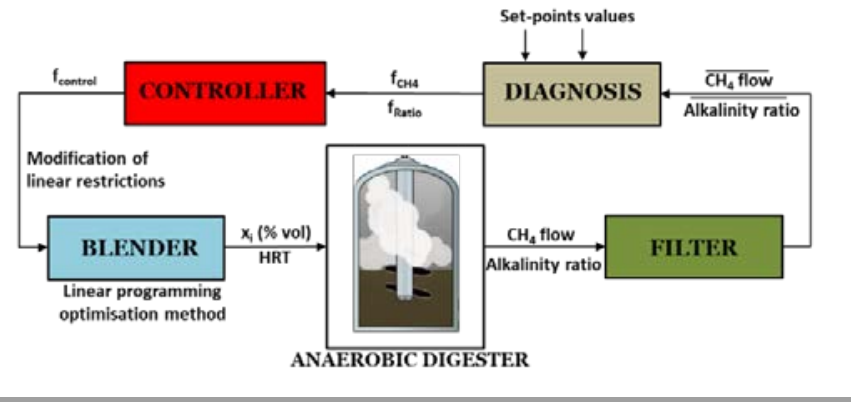

Fig. 1 Optimum closed-loop control strategy for anaerobic codigestion (adapted from Garcia-Gen et al. (2015). ${ }^{18}$

\section{Optimum substrates blender block}

Firstly, the substrate blender block based on linear programming calculates the feeding mixture and the HRT (and consequently, the OLR) for maximum methane productivity, subjected to a set of linear restrictions that are established based on the heuristic knowledge of 
the AD process. ${ }^{19}$ The inputs of the optimisation method are the physico-chemical characterization and the BMP of each waste. The set of linear restrictions and their maximum and minimum limits are established based on heuristic knowledge and expertise on $A D$ process: (i) OLR, (ii) TKN, (iii) moisture, (iv) lipids, (v) $\mathrm{Na}^{+}$, (vi) $\mathrm{K}^{+}$, (vii) $\mathrm{H}_{2} \mathrm{~S}$ concentration in biogas and (viii) effluent biodegradable COD. Moreover, in this case this set was complemented with extra restrictions required by the full-scale scenario: ix) the flowrate of sewage sludge generated in the WWTP must be fully treated in the digester. Initial boundaries of the restrictions are shown in Table 1.

Table 1 Set of restrictions and their initial boundaries considered for the optimisation method (adapted from Garcia-Gen et al. (2015)). ${ }^{18}$

\begin{tabular}{|c|c|c|}
\hline Linear restriction & Minimum & Maximum \\
\hline OLR (g COD/(L·d)) & 0 & 1.5 \\
\hline N-TKN (g/kg) & 0.2 & 4 \\
\hline Moisture $\left(\mathrm{kg} \mathrm{H} \mathrm{H}_{2} \mathrm{O} / \mathrm{kg}\right.$ ) & 0.85 & 1 \\
\hline Lipids (g/kg) & 0 & 20 \\
\hline $\mathrm{Na}^{+}(\mathrm{g} / \mathrm{kg})$ & 0 & 3 \\
\hline $\mathrm{K}^{+}(\mathrm{g} / \mathrm{kg})$ & 0 & 3 \\
\hline Biogas quality (ppm $\mathrm{H}_{2} \mathrm{~S}$ ) & 0 & 10,000 \\
\hline Digestate quality (g COD biodegradable $/ \mathrm{kg}$ ) & 0 & 6 \\
\hline Sewage sludge flowrate ( $\mathrm{m}^{3} /$ month) & 4,000 & 4,500 \\
\hline
\end{tabular}

\section{Filter block}

The Filter module calculates the values of the physico-chemical parameters monitored in the reactor and used as diagnosis indicators, alkalinity ratio and methane flow. For methane flow, the average value is always used in the diagnosis block. For alkalinity ratio, the average value is used when the standard deviation of this parameter is lower than $20 \%$ of the average value. If standard deviation is higher than $20 \%$, last alkalinity ratio is used. This modification was done to avoid overloading the system when a potential trend of increasing alkalinity ratio is observed.

\section{Diagnosis block}

The Diagnosis module informs about the stability of the process and methane production performance through the alkalinity ratio and methane flow parameters. Alkalinity ratio (Ratio) is defined as the ratio between the intermediate alkalinity $(\mathrm{IA})$ and TA. This term indicates the stability of the system (values below 0.3 indicate the stability of the process against VFA accumulation). Average methane flow is used as an indicator of the maximum methane production capacity of the system. Diagnosis function compares both measured diagnosis parameters (alkalinity ratio and methane production) against set-point values (Figure 2) based on empirical correlations and explained in detail by García-Gen et al. (2015) ${ }^{18}$. It returns two diagnosis factors based on these indicators: stability factor $\left(f_{\text {Ratio, }}\right.$ Figure $2 \mathrm{~A}$ ) and remaining methanogenic potential factor $\left(\mathrm{f}_{\mathrm{CH} 4}\right.$, Figure 2B).

\section{Controller block}

The Controller module calculates the control indicator, $\mathrm{f}_{\text {Control, }}$ as the product of $\mathrm{f}_{\text {Ratio }}$ and $\mathrm{f}_{\mathrm{CH} 4}$ when the system is stable ( $\mathrm{f}_{\text {Ratio }}$ achieves a positive value), or equal to $f_{\text {Ratio }}$ when systems becomes unstable and $f_{\text {Ratio }}$ is negative (Equation 1$)$.

$$
f_{\text {control }}\left\{\begin{array}{lll}
f_{\text {Ratio }} \cdot f_{C H 4} & \text { if } & f_{\text {Ratio }}>0 \\
f_{\text {Ratio }} & \text { if } & f_{\text {Ratio }} \leq 0
\end{array}\right.
$$

The value of $f_{\text {Control }}$ varies between $[-1,1]$ and determines the quantitative change applied to the boundary of the most active constraint of the linear programming method (equation 2), leading to a new substrate blend and HRT.

Limit $_{\text {NEW }}=$ Limit $_{A C T U A L}+\boldsymbol{f}_{\text {control }} \cdot\left(\right.$ LIMIT $_{\text {HIGHER }}-$ LIMIT $\left._{\text {LOWER }}\right)$ (2)

When the system is stable ( $f_{\text {control }}$ positive), the control promotes the use of feedings with higher methane production potential. By relaxing the limits of the restrictions, the Blender output achieves a higher value of the objective function; consequently, higher OLR are applied and higher methane productions are obtained. Under destabilisation episodes ( $f_{\text {control }}$ negative) the control promotes the use of feeding with lower methane production in order to prevent the system from a possible acidification. By constraining the limits of the restrictions, the Blender output leads to lower values of objective function methane productivity.
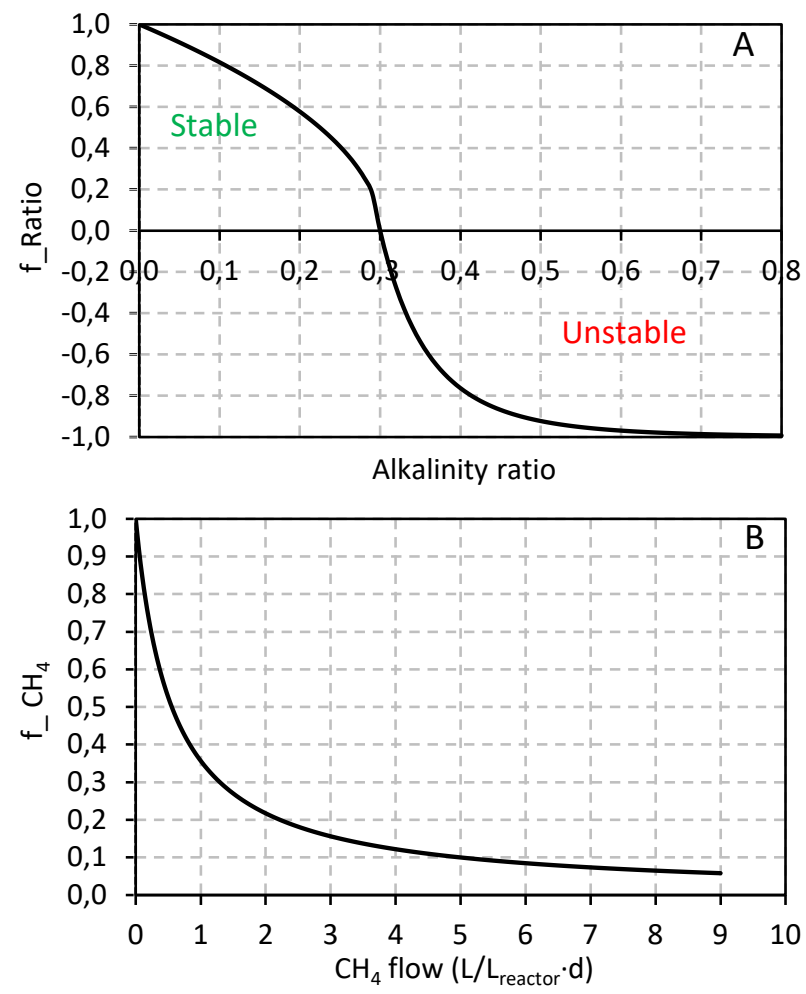

Fig. 2 Function of the stability factor $(A)$ and methane production factor (B) (adapted from Garcia-Gen et al. (2015)). ${ }^{18}$

\section{Analytical methods}

$\mathrm{pH}, \mathrm{COD}, \mathrm{TS}, \mathrm{VS}, \mathrm{TKN}, \mathrm{TAN}, \mathrm{TA}$ and PA were determined following Standard Methods. ${ }^{21}$ Protein concentration (Pr) was estimated by multiplying the organic nitrogen (TKN minus TAN) by 6.25. ${ }^{22}$ Lipids (Lp) and carbohydrates (Ch) were determined by the simultaneous resolution of equations (3) and (4), assuming COD values of $1.1 \mathrm{~g}$ $\mathrm{COD} / \mathrm{g}$ carbohydrate, $1.3 \mathrm{~g}$ COD/protein and $2.9 \mathrm{~g}$ COD/g lipid. ${ }^{23,24}$

$C O D=1.3 \cdot P r+1.1 \cdot C h+2.9 \cdot L p$ 
$V S=P r+C h+L p$

VFA (acetic, propionic, i-butyric, n-butyric, i-valeric and n-valeric) were analysed by gas chromatography equipped with a Flame Ionization Detector (FIC, HP 5890A). $\mathrm{SO}_{4}{ }^{2-}$ and cations $\left(\mathrm{Na}^{+}\right.$and $\mathrm{K}^{+}$) were determined following ASTM D4327-03 and ASTM D6919-03 methods, respectively (ASTM, 2003). Biogas production was measured with a pressure transducer (Centrepoints electronics) in BMP tests and with a $\mu$ Flow meter (Bioprocess Control, Sweden) in the lab-scale reactor and corrected to normal temperature and pressure $\left(0^{\circ} \mathrm{C}\right.$ and $\left.101.325 \mathrm{kPa}\right)$. Biogas composition was analysed by gas chromatography (HP, 5890 Series II).

\section{Results and discussion}

\section{Physico-chemical characterization of wastes}

Table 2 shows the main physico-chemical characteristics of sewage sludge, residue $A$ and residue $B$. The characteristics of sewage sludge were in the typical reported range. ${ }^{25,26}$ Residues $A$ and $B$ display high TS concentrations, ranging from $60.8 \pm 5.4 \mathrm{~g} \mathrm{TS} / \mathrm{kg}$ (residue A) to 158 $\mathrm{g} \mathrm{TS} / \mathrm{kg} \pm 37$ (residue B), with an elevated percentage of VS (88 and $94 \%$ of TS for residues A and B, respectively) and high COD content $(119 \pm 16$ and $360 \pm 91 \mathrm{~g} \mathrm{COD} / \mathrm{kg}$, respectively). They present higher levels of nitrogen $(4.4 \pm 0.1$ and $5.2 \pm 0.6 \mathrm{~g} \mathrm{~N}-\mathrm{TKN} / \mathrm{kg})$ and lipids $(31.5$ \pm 6.4 and $83.8 \pm 15.9 \mathrm{~g} / \mathrm{kg}$ ) than those reported as inhibitory in the literature, ${ }^{27,28}$ which limits their proportions in the feeding mixture. Overall, the characteristics of residues A and B are similar to other food wastes, ${ }^{29,30}$ taking into account that this type of waste displays high variability in the composition depending on its nature. ${ }^{31}$

Table 2 Average physico-chemical characteristics of sewage sludge $(n=4)$, residue $A(n=4)$ and residue $B(n=3)$ with their standard deviations.

\begin{tabular}{|c|c|c|c|}
\hline Parameter & $\begin{array}{l}\text { Sewage } \\
\text { sludge }\end{array}$ & Residue A & Residue B \\
\hline $\mathrm{pH}$ & $5.9 \pm 0.4$ & $6.6 \pm 0.9$ & $3.8 \pm 0.3$ \\
\hline $\mathrm{COD}\left(\mathrm{g} \mathrm{O}_{2} / \mathrm{kg} \mathrm{ww}\right)$ & $45.5 \pm 15.1$ & $119 \pm 16$ & $360 \pm 91$ \\
\hline TS (g/kg ww) & $50.2 \pm 22.3$ & $60.8 \pm 5.4$ & $158 \pm 37$ \\
\hline VS (g/kg ww) & $26.6 \pm 10.6$ & $53.3 \pm 5.3$ & $150 \pm 39$ \\
\hline $\mathrm{TA}\left(\mathrm{g} \mathrm{CaCO}_{3} / \mathrm{kg} \mathrm{ww}\right)$ & $0.4 \pm 0.3$ & $2.9 \pm 1.2$ & 0 \\
\hline TKN (g N-TKN/kg ww) & $1.7 \pm 0.6$ & $4.4 \pm 0.1$ & $5.2 \pm 0.6$ \\
\hline TAN (g N- TAN/kg ww) & $0.7 \pm 0.2$ & $1.7 \pm 0.5$ & $0.6 \pm 0.1$ \\
\hline Lipids (g/kg ww) & $7.1 \pm 3.3$ & $31.5 \pm 6.4$ & $83.8 \pm 15.9$ \\
\hline Carbohydrates (g/kg ww) & $11.5 \pm 1.8$ & $5.0 \pm 0.9$ & $15.0 \pm 2.5$ \\
\hline Proteins (g/kg ww) & $6.1 \pm 2.3$ & $16.6 \pm 2.7$ & $28.5 \pm 3.3$ \\
\hline $\mathrm{Na}^{+}(\mathrm{g} / \mathrm{kg} \mathrm{ww})$ & $0.09 \pm 0.02$ & $0.43 \pm 0.10$ & $0.17 \pm 0.01$ \\
\hline $\mathrm{K}^{+}(\mathrm{g} / \mathrm{kg} \mathrm{ww})$ & $0.08 \pm 0.03$ & $0.15 \pm 0.08$ & $0.10 \pm 0.05$ \\
\hline $\mathrm{SO}_{4}^{2-}(\mathrm{g} / \mathrm{kg} \mathrm{ww})$ & $0.07 \pm 0.04$ & $0.02 \pm 0.02$ & $0.01 \pm 0.01$ \\
\hline Acetic acid (mg /kg ww) & $110-770$ & $1,350-2,150$ & $1,080-2,800$ \\
\hline Propionic acid (mg/kg ww) & $50-400$ & $940-1,780$ & $260-1,050$ \\
\hline Butyric acids (mg /kg ww) & $20-130$ & $820-1,440$ & $20-2,040$ \\
\hline Valeric acids (mg / kg ww) & $10-100$ & $810-1,400$ & $10-1,180$ \\
\hline
\end{tabular}

Biomethane potential of wastes
BMP of sewage sludge, residue $A$ and residue $B$ are shown in Figure 3. No lag phase was observed for sewage sludge and residue $A$, and two different stages could be distinguished: a fast methane production (during the first three and five days of the test, respectively) followed by a slow methane production till the end of the test. Conversely, residue B presented a lag phase of four days followed by five days of fast methane production. From day 9 on, methane production rate decreased till the end of the test.

The methane potential of sewage sludge was $368 \pm 19 \mathrm{~L}(\mathrm{~N}) \mathrm{CH}_{4} / \mathrm{kg}$ VS $(55.0 \pm 3.1 \%$ of anaerobic biodegradability), which is in the range of other reported values. ${ }^{32}$ Residue A presented a higher BMP value (649 $\pm 38 \mathrm{~L}(\mathrm{~N}) \mathrm{CH}_{4} / \mathrm{kg}$ VS $(77.7 \pm 3.9 \%)$, comparable to other results in the literature for slaughterhouse wastes. ${ }^{33}$ Residue $\mathrm{B}$ presented the highest BMP values $\left(691 \pm 23 \mathrm{~L}(\mathrm{~N}) \mathrm{CH}_{4} / \mathrm{kg}\right.$ VS $(82.8 \pm 4.5 \%)$, respectively), similar to the values reported by Cabbai et al. (2013) ${ }^{34}$ for food wastes from restaurants which presented also important proteins and lipids concentrations. The high methane yields obtained show that these residues are appropriate co-substrates.

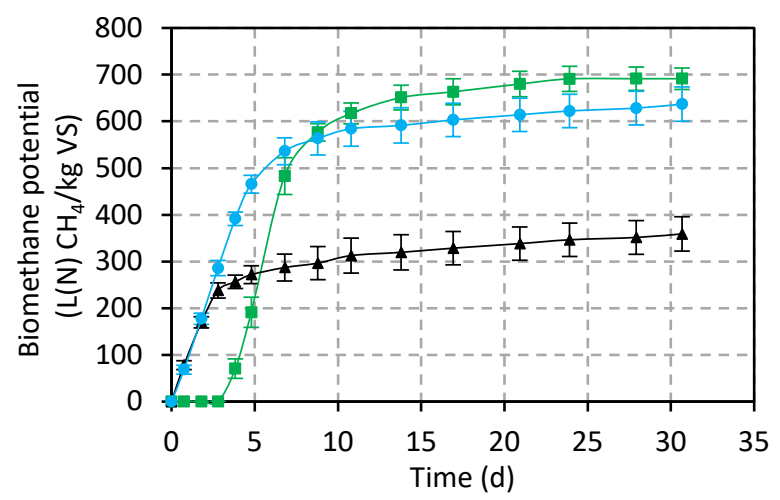

Fig. 3 Average and standard deviation biomethane potential of sewage sludge $(\boldsymbol{\Delta})$, residue $A(\bullet)$ and residue $B(\bullet)$.

The neutral $\mathrm{pH}$ value $(7.38 \pm 0.02,7.36 \pm 0.02$ and $7.36 \pm 0.01$ for sewage sludge, residue $A$ and residue $B$, respectively) and the absence of VFA ( $<2.5 \mathrm{ppm}$ acetic acid) at the end of the BMP test indicate that the performance of the test was adequate and no acidification occurred.

\section{Anaerobic co-digestion optimisation}

Considering the sludge generated $\left(4,000-4,500 \mathrm{~m}^{3}\right.$ monthly) and the availability of the two co-substrates (400 and $160 \mathrm{~m}^{3}$ monthly for residues $A$ and $B$, respectively), the operational conditions that maximize methane production are: a feeding mixture 89:8:3 of sewage sludge: residue $A$ : residue $B$ of $(w / w)$ and a HRT of 20 days, with an OLR of $3.5 \mathrm{~g} \mathrm{COD} /(\mathrm{L} \cdot \mathrm{d})$. The restriction for sewage sludge flow was maintained in 4,000-4,500 $\mathrm{m}^{3} /$ month throughout the operation, (i.e. the whole amount of sewage sludge produced must be fed to the digester). However, the restriction for the availability of the two co-substrates was only considered for the optimised scenario, since for short-term periods the co-substrates flow rate could exceed their generation as long as they are previously accumulated and storaged.

\section{Safe steering from anaerobic mono- to co-digestion at lab-scale}

The operational strategy to achieve the established final conditions can be divided into different periods (Table 3 ). 
Table 3 Composition of the feeding mixture, organic loading rate (OLR), hydraulic retention time (HRT), duration and values of the diagnosis indicators during each experimental period of the lab-scale anaerobic reactor

\begin{tabular}{|c|c|c|c|c|c|c|c|c|c|c|c|}
\hline Period & $\begin{array}{l}\text { Duration } \\
\text { (d) }\end{array}$ & $\begin{array}{l}\text { Sewage sludge } \\
(\% \mathrm{w} / \mathrm{w})\end{array}$ & $\begin{array}{l}\text { Residue A } \\
(\% \mathrm{w} / \mathrm{w})\end{array}$ & $\begin{array}{l}\text { Residue B } \\
(\% \mathrm{w} / \mathrm{w})\end{array}$ & $\begin{array}{l}\text { OLR } \\
(\mathrm{g} C O D /(L \cdot d))\end{array}$ & $\begin{array}{l}\text { HRT } \\
\text { (d) }\end{array}$ & $\begin{array}{l}\text { Alkalinity } \\
\text { ratio }\end{array}$ & $f_{\text {ratio }}$ & $\begin{array}{l}\text { Methane flow } \\
(\mathrm{L} / \text { (Lreactor } \cdot \mathrm{d})\end{array}$ & $\mathrm{f}_{\mathrm{CH} 4}$ & $f_{\text {control }}$ \\
\hline I & $1-17$ & 100 & 0 & 0 & 1.3 & 30 & $0.20 \pm 0.01$ & - & - & - & - \\
\hline ॥ & $18-24$ & 95 & 5 & 0 & 1.6 & 25 & $0.20 \pm 0.00$ & 0.58 & $0.20 \pm 0.06$ & 0.75 & 0.46 \\
\hline III & $25-82$ & 80 & 14 & 6 & 2.4 & 20 & $0.23 \pm 0.01$ & 0.48 & $0.64 \pm 0.12$ & 0.46 & 0.21 \\
\hline IV & $83-117$ & 80 & 7 & 13 & 2.8 & 20 & $0.23 \pm 0.01$ & 0.48 & $0.82 \pm 0.06$ & 0.40 & 0.19 \\
\hline V & 118-145 & 85 & 0 & 15 & 3.3 & 20 & $0.21 \pm 0.01$ & 0.55 & $0.91 \pm 0.06$ & 0.38 & 0.21 \\
\hline $\mathrm{VI}$ & $146-180$ & 89 & 8 & 3 & 3.5 & 20 & $0.22 \pm 0.02$ & 0.52 & $0.71 \pm 0.03$ & 0.44 & - \\
\hline
\end{tabular}

During the mono-digestion period (Figure 4, period I), methane production was $0.57 \mathrm{~g} \quad \mathrm{CH}_{4}-\mathrm{COD} /(\mathrm{L} \cdot \mathrm{d}) \quad\left(0.20 \mathrm{~L}(\mathrm{~N}) \quad \mathrm{CH}_{4} /(\mathrm{L} \cdot \mathrm{d})\right)$, corresponding to a degradation of $50-55 \%$. In period II, optimisation

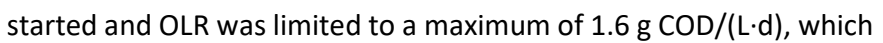
was close to the OLR of period I, to avoid the double perturbation of increasing OLR and adding new substrates. Under these restrictions, the optimal operational conditions calculated by the optimisation method were a blend 95:5:0 (w/w) of sewage sludge: residue $A$ : residue $B$ and a HRT of 25 days (period II, Table 3). No changes in methane production were observed (Figure 4, period II), and consequently, the degradation decreased (40\%). After the diagnosis of the digester performance (period II, Table 3), the optimisation method increased the upper boundary of the OLR to $2.4 \mathrm{~g} \mathrm{COD/(L \cdot d)}$ in period III. The blend obtained was 80:14:6 (w/w) of sewage sludge: residue A: residue $B$, and a HRT of 20 days (period III, Table 3). Under these conditions, methane production increased to $1.9 \mathrm{~g} \mathrm{CH}_{4^{-}}$ $\mathrm{COD} /(\mathrm{L} \cdot \mathrm{d})\left(0.64 \mathrm{~L}(\mathrm{~N}) \mathrm{CH}_{4} /(\mathrm{L} \cdot \mathrm{d})\right.$, Figure 4), resulting in a degradation of $75 \%$, which was in accordance with the higher anaerobic biodegradability of the co-substrates. To adapt the digester microorganisms to the co substrates, these conditions were maintained during a period equivalent to 3 HRT. After almost 60 days of stable operation, the diagnosis (period III, Table 3 ) allowed to increase the upper boundary of the OLR to $2.8 \mathrm{~g} \mathrm{COD} /(\mathrm{L} \cdot \mathrm{d})$ during period IV. A mix 80:7:13 (w/w) of sewage sludge: residue A: residue $B$ (period IV, Table 3) was calculated, maintaining the HRT of 20 days. These conditions resulted in higher methane production $\left(2.3 \mathrm{~g} \mathrm{CH}_{4}-\right.$ $\mathrm{COD} /(\mathrm{L} \cdot \mathrm{d})\left(0.82 \mathrm{~L}(\mathrm{~N}) \mathrm{CH}_{4} /(\mathrm{L} \cdot \mathrm{d})\right)$, Figure 4$)$ and degradation (82\%). After 30 days of operation, the diagnosis system calculated an upper boundary for the OLR of $3.3 \mathrm{~g} \mathrm{COD} /(\mathrm{L} \cdot \mathrm{d})$ in period $\mathrm{V}$. The mix obtained was 85:0:15 (w/w) of sewage sludge: residue A: residue $B$ and a HRT of20 days (period $V$, Table 3 ). Under these conditions, methane production slightly increased to $2.6 \mathrm{~g} \mathrm{CH}_{4}-\mathrm{COD} /(\mathrm{L} \cdot \mathrm{d})$ (0.91 L(N) $\mathrm{CH}_{4} /(\mathrm{L} \cdot \mathrm{d})$, Figure 4$)$, but degradation decreased to $78 \%$. After one month of operation, the efficiency and stability of the digester were confirmed through the diagnosis indicators (period V, Table 3), and consequently, the established optimal conditions a mix 89:8:3 (w/w) of sewage sludge: residue $A$ : residue $B$, with an OLR of $3.5 \mathrm{~g} \mathrm{COD/(L \cdot d)}$ and HRT of 20 days, period $\mathrm{VI}$, Table 3 ) were directly applied in period VI. These conditions led to lower methane production $\left(2.1 \mathrm{~g} \mathrm{CH}_{4}^{-}\right.$ $\mathrm{COD} /(\mathrm{L} \cdot \mathrm{d})\left(0.71 \mathrm{~L}(\mathrm{~N}) \mathrm{CH}_{4} /(\mathrm{L} \cdot \mathrm{d})\right)$, Figure 4) and a degradation (60\%) due to the increase of sewage sludge COD proportion in detriment of co-substrates (corresponding to a batch of sludge with higher COD).

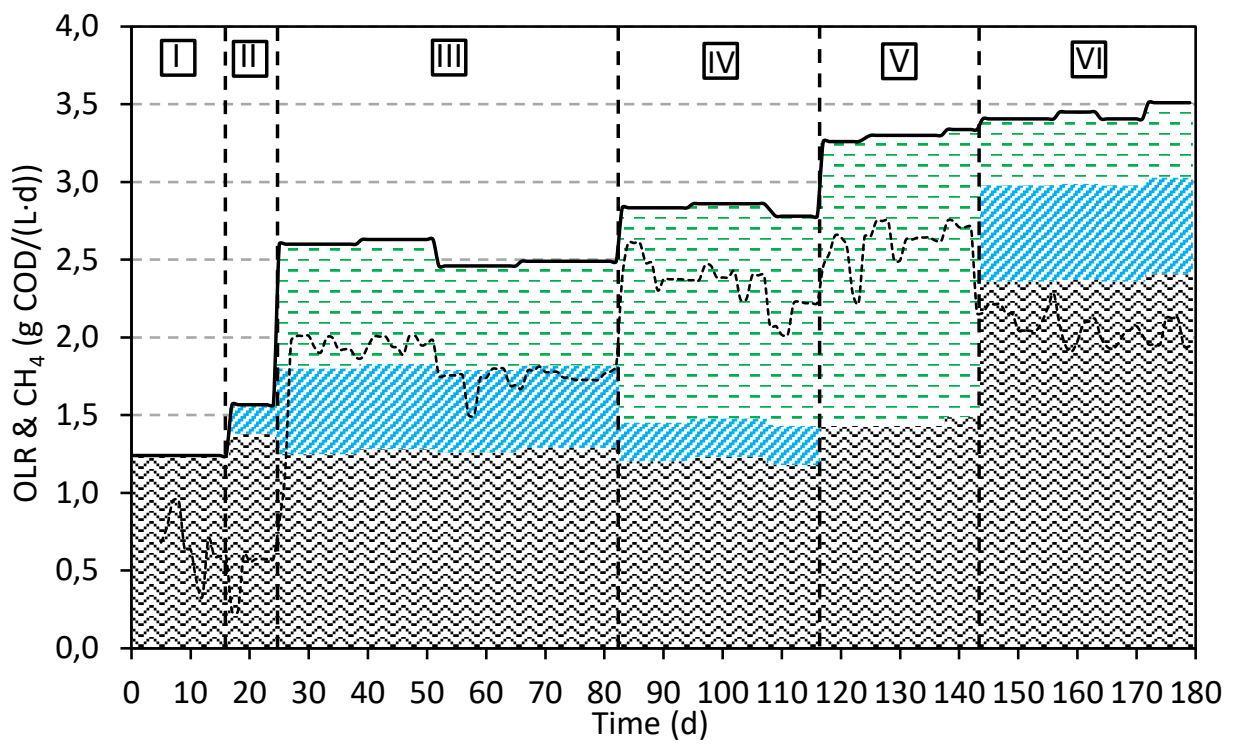

Fig. 4 Organic loading rate $\left(\mathrm{OLR}_{1}-\right)$ and methane production (--) in the lab-scale reactor. OLR of each substrate: sewage sludge ( 2 ), residue $\mathrm{A}(\mathscr{\mathscr { C }})$ and residue $\mathrm{B}\left(\mathrm{L}^{--}-\mathrm{C}\right)$. 
Despite the methane production in this period was lower than in periods IV and V, it must be pointed out that the latter scenarios were not realistic at long- term since the flowrate of residue $B$ in both periods exceeded its generation. These conditions were maintained for 40 days (2 HRT) and the diagnosis indicators showed that the operation was safe (period VI, Table 3 ) so the lab-scale digester was stopped. TAN levels in the digester increased with the addition of cosubstrates from 0.9 to $1.8 \mathrm{~g} \mathrm{~N}$-TAN/L (data not shown) due to the higher TKN content of the co-substrates. This concentration was in the same range of those reported for other digesters treating different substrates mixes ${ }^{35}$ and considerably lower than the values reported as inhibitory for mesophilic AD. ${ }^{27}$ No major differences in biogas composition were found, with a methane concentration of 63 $\pm 3 \%$ throughout the operation (data not shown). VFAs concentrations were much lower than those values considered as inhibitory ${ }^{36}$ reaching maximum acetic acid and propionic acid concentrations of 140 and $50 \mathrm{ppm}$, respectively (data not shown). $\mathrm{pH}$ was stable (7.3-7.7) and PA and TA remained constant (2.8-3.8 and 3.5-4.5 $\mathrm{g} \mathrm{CaCO}_{3} / \mathrm{L}$, respectively) throughout the operation (Figure 5), except between days 115-140, when they decreased to 2.0 and $2.5 \mathrm{~g} \mathrm{CaCO}_{3} / \mathrm{L}$, respectively, attributed to the absence of residue $A$ in the feeding (period $V$ ), since it presented an important concentration of ammonium (Table 2), increasing the digester $\mathrm{pH}$. To re-establish alkalinity levels, $1 \mathrm{~g} / \mathrm{L}$ of $\mathrm{NaHCO}_{3}$ was added to the reactor on days 133 and 137.

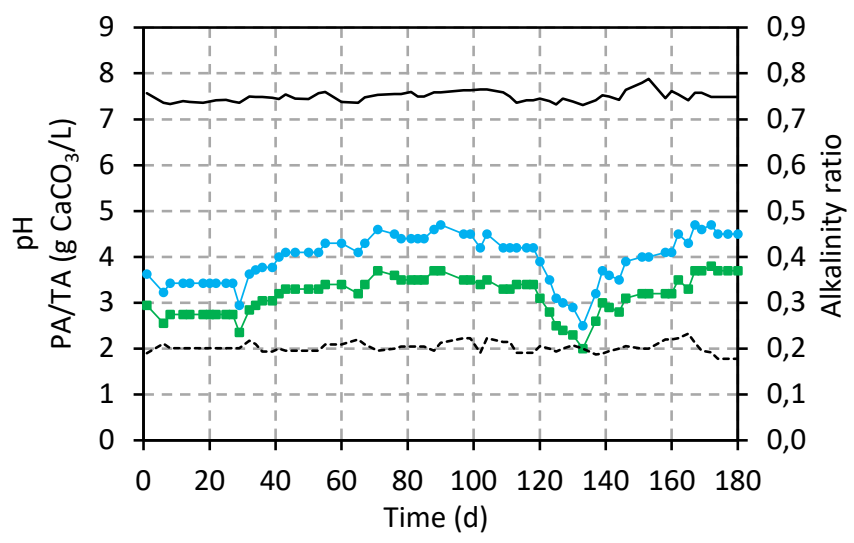

Fig. $5 \mathrm{pH}(-)$, total alkalinity $(\bullet)$, partial alkalinity $(\square)$, and alkalinity ratio (--) in the lab-scale anaerobic digester.

\section{Safe steering from anaerobic mono- to co-digestion at full-scale}

The optimisation of the full-scale digester was also conducted in 7 different steps (Figure 6). The only difference with the lab-scale one was that in the full-scale digester Residue $A$ was included in the substrates blend during period $V$ to avoid the loss of alkalinity. The blend 85:0:15 of sewage sludge: residue $A$ : residue $B$ of $(w / w)$ was successfully substituted by $85: 5: 10$ of sewage sludge: residue $A$ : residue $B(w / w)$ (period $V$, Figure 5$)$ since the alkalinity drop produced in the lab-scale digester was avoided. Overall, the results were very comparable to those of the lab-scale digester, reaching in the last period an OLR and methane production 2-fold and 3-fold higher, respectively, than during the mono-digestion period. This allowed to increase the self-produced energy of the WWTP from 25\% to $75 \%$.

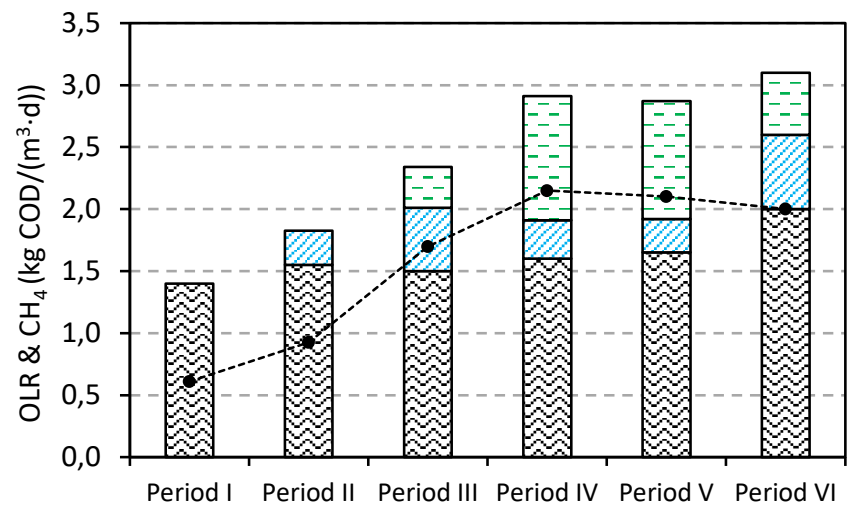

Fig. 6 Organic loading rate (OLR) of each substrate: sewage sludge (ख) $)$, residue A $(\mathbb{W})$ and residue $\mathrm{B}(\mathrm{C})$ and methane production (- $\bullet$-) in the full-scale anaerobic digester.

Developing methodologies to ensure operational stability and take actions to revert possible process destabilization becomes fundamental to make AcoD a more attractive alternative at full-scale plants. This paper proves the benefits of following a planned strategy to attain a successful transition from anaerobic mono- to codigestion. In fact, there are many examples in the literature in which the variation of the feeding composition led to a rapid or progressive failure of the digester. ${ }^{17,20,37}$ Whereas in lab-scale studies a reactor inhibition can be easily solved by re-inoculation, at full-scale plants this in not feasible since it means a very important cost. There are also a few papers in the literature reporting a noticeable increase of biogas production through AcoD operation at full-scale plants, 12,14,15 although it is not clear how they guarantee the stability of the digester and if the results could be much more favourable when using optimising tools as the one applied in this paper.

\section{Conclusions}

The proposed optimised control system provides the steps to ensure a safe transition, from anaerobic mono- to co-digestion operation at full-scale plants and the diagnosis indicators appear as sufficiently accurate to give enough information about the state of the digesters and proved to be as a solid base to take decisions concerning wastes blending and increasing the organic loading rate. It was also proved that a previous operation at lab-scale was extremely useful to foresee and avoid any operational destabilization in the full-scale digester. In this scenario, in less than six months methane production was 3-fold raised respect to the mono-digestion period, increasing the self-produced energy from $25 \%$ to $75 \%$ of the wastewater treatment plant demand.

\section{Conflicts of interest}

There are no conflicts to declare.

\section{Acknowledgements}

This work was supported by SmartGreenGas project (Spanish Government, AEI, 2014-CE224). The authors from Universidade de Santiago de Compostela belong to the Galician Competitive Research Group ED431C 2017/029 and to the CRETUS Strategic Partnership (AGRUP2017/01). All these programs are co-funded by FEDER (EU). The authors gratefully acknowledge the staff of Guillarei WWTP and 'Consorcio de Augas do Louro' for their assistance. 


\section{Notes and references}

1. Y. Gu, Y. Li, X. Li, P. Luo, H. Wang, Z.P. Robinson, X. Wang, J. $\mathrm{Wu}, \mathrm{F}$. Li, The feasibility and challenges of energy selfsufficient wastewater treatment plants, Appl. Energy. 204 (2017) 1463-1475.

2 A.L. Smith, T. Shimada, L. Raskin, A comparative evaluation of community structure in full-scale digesters indicates that two-phase digesters exhibit greater microbial diversity than single-phase digesters, Environ. Sci. Water Res. Technol. 3 (2017) 304-311.

3 P. Gikas, Towards energy positive wastewater treatment plants, J. Environ. Manage. 203 (2017) 621-629.

4 J. Wan, J. Gu, Q. Zhao, Y. Liu, COD capture: A feasible option towards energy self-sufficient domestic wastewater treatment, Sci. Rep. 6 (2016) 1-9.

5 H. Gao, Y.D. Scherson, G.F. Wells, Towards energy neutral wastewater treatment : methodology and state of the art, Environ. Sci. Process. Impacts. 16 (2014) 1223-1246. S. Longo, B.M. d'Antoni, M. Bongards, A. Chaparro, A Cronrath, F. Fatone, J.M. Lema, M. Mauricio-Iglesias, A. Soares, A. Hospido, Monitoring and diagnosis of energy consumption in wastewater treatment plants. A state of the art and proposals for improvement, Appl. Energy. 179 (2016) 1251-1268.

7 A. Serrano, J.A. Siles, M.A. Martín, A.F. Chica, F.S. EstévezPastor, E. Toro-Baptista, Improvement of anaerobic digestion of sewage sludge through microwave pretreatment, J. Environ. Manage. 177 (2016) 231-239. S. Xie, M.J. Higgins, H. Bustamante, B. Galway, L.D. Nghiem, Current status and perspectives on anaerobic co-digestion and associated downstream processes, Environ. Sci. Water Res. Technol. 4 (2018) 1759-1770.

A. Khalid, M. Arshad, M. Anjum, T. Mahmood, L. Dawson, The anaerobic digestion of solid organic waste, Waste Manag. 31 (2011) 1737-1744.

J. Mata-Alvarez, J. Dosta, S. Macé, S. Astals, Codigestion of solid wastes: A review of its uses and perspectives including modeling, Crit. Rev. Biotechnol. 31 (2011) 99111.

11 J. Mata-Alvarez, J. Dosta, M.S. Romero-Güiza, X. Fonoll, M. Peces, S. Astals, A critical review on anaerobic co-digestion achievements between 2010 and 2013, Renew. Sustain. Energy Rev. 36 (2014) 412-427.

12 L.D. Nghiem, K. Koch, D. Bolzonella, J.E. Drewes, Full scale co-digestion of wastewater sludge and food waste: Bottlenecks and possibilities, Renew. Sustain. Energy Rev. 72 (2017) 354-362

13 S. Xie, F.I. Hai, X. Zhan, W. Guo, H.H. Ngo, W.E. Price, L.D. Nghiem, Anaerobic co-digestion : A critical review of mathematical modelling for performance optimization, Bioresour. Technol. 222 (2016) 498-512.

14 D. Bolzonella, P. Battistoni, C. Susinii, F. Cecchi, Anaerobic codigestion of waste activated sludge and OFMSW: the experiences of viareggio and treviso plants (Italy)., Water Sci. Technol. 53 (2006) 203-211.
Dewulf, P. Boeckx, S.E. Vlaeminck, B. Wett, Environmental sustainability of an energy self-sufficient sewage treatment plant: Improvements through DEMON and co-digestion, Water Res. 74 (2015) 166-179. 16

16. G.H.R. Braz, N. Fernandez-Gonzalez, J.M. Lema, M Carballa, The time response of anaerobic digestion microbiome during an organic loading rate shock, Appl. Microbiol. Biotechnol. 102 (2018) 10285-10297.

A.Q. Nguyen, R. Wickham, L.N. Nguyen, H. V Phan, B. Galway, H. Bustamante, L.D. Nghiem, Impact of anaerobic co-digestion between sewage sludge and carbon-rich organic waste on microbial community resilience, Environ. Sci. Water Res. Technol. 4 (2018) 1956-1965.

S. García-Gen, J. Rodríguez, J.M. Lema, Control strategy for maximum anaerobic co-digestion performance, Water Res. 80 (2015) 209-216.

S. García-Gen, J. Rodríguez, J.M. Lema, Optimisation of substrate blends in anaerobic co-digestion using adaptive linear programming, Bioresour. Technol. 173 (2014) 159167.

I. Rodriguez-Verde, L. Regueiro, R. Pena, J.A. Álvarez, J.M. Lema, M. Carballa, Feasibility of spent metalworking fluids as co-substrate for anaerobic co-digestion, Bioresour. Technol. 155 (2014) 281-288.

APHA, Standard Methods for the Examination of Water and Wastewater, 21st ed. American Public Health Association/American Water Works Association/Water Environment Federation, Washington DC, USA., American Public Health Association, Washington DC, 2005 F.R. Dintzis, J.F. Cavins, E. Graf, T. Stahly, Nitrogen-toprotein conversion factors in animal feed and fecal samples., J. Anim. Sci. 66 (1988) 5-11.

L. Neves, R. Oliveira, M.M. Alves, Fate of LCFA in the codigestion of cow manure, food waste and discontinuous addition of oil, Water Res. 43 (2009) 5142-5150.

A.H. Stouthamer, A theoretical study on the amount of ATP required for synthesis of microbial cell material, Antonie Van Leeuwenhoek. 39 (1973) 545565.

L. Berthod, G. Roberts, A. Sharpe, D.C. Whitley, R.

Greenwood, G.A. Mills, Effect of sewage sludge type on the partitioning behaviour of pharmaceuticals: a meta-analysis, Environ. Sci. Water Res. Technol. 2 (2016) 154-163. L. Gonzalez-Gil, M. Papa, D. Feretti, E. Ceretti, G. Mazzoleni, N. Steimberg, R. Pedrazzani, G. Bertanza, J.M. Lema, M. Carballa, Is anaerobic digestion effective for the removal of organic micropollutants and biological activities from sewage sludge?, Water Res. 102 (2016) 211-220. Y. Chen, J.J. Cheng, K.S. Creamer, Inhibition of anaerobic digestion process: A review, Bioresour. Technol. 99 (2008) 4044-4064.

Y.Y. Li, H. Sasaki, K. Yamashita, K. Seki, I. Kamigochi, Highrate methane fermentation of lipid-rich food wastes by a high-solids co-digestion process, Water Sci. Technol. 45 (2002) 143 LP-150. substrates for co-digestion through biochemical methane 
potential (BMP) experiments, Waste Manag. 33 (2013) 2664-2669.

M. Zamanzadeh, L.H. Hagen, K. Svensson, R. Linjordet, S.J. Horn, Anaerobic digestion of food waste - Effect of recirculation and temperature on performance and microbiology, Water Res. 96 (2016) 246-254.

31 E. Iacovidou, D.G. Ohandja, N. Voulvoulis, Food waste codigestion with sewage sludge - Realising its potential in the UK, J. Environ. Manage. 112 (2012) 267-274..

32 S. Astals, M. Esteban-Gutiérrez, T. Fernández-Arévalo, E. Aymerich, J.L. García-Heras, J. Mata-Alvarez, Anaerobic digestion of seven different sewage sludges: A biodegradability and modelling study, Water Res. 47 (2013) 6033-6043.

33 A. Hejnfelt, I. Angelidaki, Anaerobic digestion of slaughterhouse by-products, Biomass and Bioenergy. 33 (2009) 1046-1054.

34 V. Cabbai, M. Ballico, E. Aneggi, D. Goi, BMP tests of source selected OFMSW to evaluate anaerobic codigestion with sewage sludge, Waste Manag. 33 (2013) 1626-1632.

35 A. Akhiar, A. Battimelli, M. Torrijos, H. Carrere, Comprehensive characterization of the liquid fraction of digestates from full-scale anaerobic co-digestion, Waste Manag. 59 (2017) 118-128. H.B. Nielsen, H. Uellendahl, B.K. Ahring, Regulation and optimization of the biogas process: Propionate as a key parameter, Biomass and Bioenergy. 31 (2007) 820-830. N. Brown, J. Güttler, A. Shilton, Overcoming the challenges of full scale anaerobic co-digestion of casein whey, Renew. Energy. 96 (2016) 425-432. 